\title{
Weight Gain
}

National Cancer Institute

\section{Source}

National Cancer Institute. Weight Gain. NCI Thesaurus. Code C62754.

An increase in total body weight. 